\title{
Pengembangan Bahan Ajar Mata Kuliah Pembelajaran IPS SD Untuk Mahasiswa PGSD Universitas Bhinneka PGRI
}

\author{
Ria Fajrin Rizqy Ana \\ Universitas Bhinneka PGRI
}

Corresponding author email: ria.fajrin@stkippgritulungagung.ac.id

\begin{tabular}{ll}
\hline & \multicolumn{1}{c}{ Abstrak } \\
\hline Kata Kunci: & Tujuan dari penelitian ini yaitu untuk mengembangkan bahan ajar mata kuliah \\
Pengembangan, & Pembelajaran IPS SD dan meningkatkan motivasi belajar mahasiswa PGSD \\
bahan ajar, four $D$ & Universitas Bhinneka PGRI. Metode yang digunakan adalah research and \\
& development $(R \& D)$ dengan model pengembangan Four D (4D). Model \\
& pengembangan 4D terdiri atas 4 tahap yaitu: Define, Design, Develop dan \\
& Disseminate. Instrumen yang digunakan angket dan soal tes. Hasil penelitian \\
& menunjukkan dari uji coba perorangan diperoleh hasil 87,5 \%, uji coba \\
& kelompok kecil (12) mahasiswa 84,17\%, uji coba lapangan pada 37 mahasiswa \\
& diperoleh hasil 90,88\%, sehingga produk buku layak digunakan untuk kegiatan \\
& pembelajaran.
\end{tabular}

\begin{tabular}{|c|c|}
\hline & Abstract: \\
\hline $\begin{array}{l}\text { Keyword: } \\
\text { Development, } \\
\text { teaching material, } \\
\text { four D }\end{array}$ & $\begin{array}{l}\text { The purpose of this research is to develop teaching materials for SD social } \\
\text { studies subjects and to increase learning motivation of PGSD students at } \\
\text { Bhinneka PGRI University. The method used is research and development } \\
\text { (R\&D) with the Four D (4D) development model. The 4D development model } \\
\text { consists of } 4 \text { stages, namely: Define, Design, Develop and Disseminate. The } \\
\text { instruments used were questionnaires and test questions. The results showed } \\
\text { that from individual trials the results obtained were } 87.5 \% \text {, small group trials } \\
\text { (12) of } 84.17 \% \text { students, field trials on } 37 \text { students obtained } 90.88 \% \text { results, so } \\
\text { that the book product was suitable for use in learning activities. }\end{array}$ \\
\hline & @Inventa:Jurnal Pendidikan Sekolah Dasar Copy Right \\
\hline
\end{tabular}

\section{Pendahuluan}

Permasalahan yang berhubungan dengan pengetahuan umum masih menjadi permasalahan pokok yang terjadi di dunia pendidikan baik di tingkat pra sekolah, sekolah dasar, sekolah menengah maupun di tingkat atas bahkan sampai di perguruan tinggi. Masalah yang dimaksud cukup beragam mulai dari minat belajar yang rendah, motivasi belajar yang kurang, hasil belajar yang rendah, rendahnya kemmapuan komunikasi, kemampuan pemecahan masalah dan permasalahan-permasalahan lainnya yang mana penyebab dari permasalahan tersebut juga karena cara guru/dosen menyampaikan materi kurang tepat, metode yang belum tepat dan penyebab-penyebab lainnya, dan buku yang tidak sesuai dengan keadaan saat ini (Yatmono, 2013). 
Di tingkat perguruan tinggi khususnya untuk Prodi PGSD, Pembelajaran IPS merupakan matakuliah wajib ditempuh mahasiswa. Pada Prodi PGSD Pembelajaran IPS SD menjadi salah satu matakuliah yang tidak bisa dilepaskan. Dari matakuliah yang diberikan tersebut masalah yang dihadapi oleh dosen pengampu sama dengan permasalahan yang disebutkan di atas khususnya pada rendahnya motivasi dan minat mahasiswa. Menurut Windari (2014) pada pembelajaran siswa diharapkan mampu menyelesaikan masalah yang meliputi kompetensi pemahaman masalah, menyelesaikan model, dan mengatasi masalah yang akan dipecahkan. Pemecahan masalah merupakan keterampilan yang dapat diformulasikan dengan teknik cara mengatasi suatu permasalahan (Bradshaw \& Hazell, 2017).

Ilmu Pengetahuan Teknologi berkembang dengan pesat. Perkembangan tersebut menjadikan tuntutan untuk berkembangnya daya fikir manusia yang berkualitas agar dapat bersaing dan tidak tertinggal. Pendidikan sebagai salah satu upaya untuk mencetak manusia yang berkualitas. Pendidikan juga digunakan sebagai sarana untuk membentuk manusia menjadi pribadi yang lebih baik, berperilaku sesuai dengan etika dan norma yang berlaku di masyarakatnya, dan menjadi pribadi yang mandiri (Wirna, 2019).
Kualitas pendidikan yang rendah dikarenakan kurang berhasilnya proses pembelajaran. Proses pembelajaran di PT selama ini selalu menempatkan mahasiswa sebagai objek yang harus diisi oleh sejumlah ragam informasi dan sejumlah bahan-bahan ajar setumpuk lainnya. Terjadinya komunikasi hanya satu arah yaitu antara dosen dan mahasiswa dimana pembelajaran cenderung menggunakan buku teks yang ada. Buku teks bahkan menjadi sumber utama dalam proses pembelajaran. Buku teks adalah hasil karya yang ditulis oleh seseorang dalam bentuk cetak yang disusun secara teratur, logis, disesuaikan dengan kebutuhan siswa, dan sistematis tentang mata pelajaran tertentu (Setyosari.P. dan Sihkabuden, 2005: 138).

Pembelajaran yang terjadi masih rendahnya motivasi dan hasil belajar mahasiswa. Salah satu cara yang dapat dilakukan untuk memperbaiki kualitas pembelajaran adalah dengan menggunakan bahan ajar yang mampu membuat mahasiswa aktif, mampu memecahkan masalah dalam kehidupannya dengan menggunakan konsep pengetahuan yang telah dipelajari, mamemahami pelajaran dengan baik, dan mengorganisasi sendiri pengetahuannya. Solusi dari permasalahan tersebut, pembelajaran disusun yang menarik dan mengembangkan keterampilan berpikir siswa. Mengingat pentingnya keterampilan tersebut maka untuk mendukung peran guru dalam 
merancang suatu pembelajaran yang dapat mengembangkan pembelajaran siswa maka diperlukan bahan ajar yang tepat sesuai dengan standar kurikulum serta dapat memunculkan hakikat pembelajaran tematik secara seimbang. Bahan ajar merupakan salah satu perangkat pembelajaran yang dapat dikembangkan oleh tenaga pendidik dengan memperhatikan kebutuhan dan kondisi di tempatnya. (Tarmidzi, 2020).

Sumber belajar dan sarana yang digunakan dalam perkuliahan masih sangat terbatas jumlahnya. Selain itu, buku ajar yang tersedia belum sesuai dengan standard yang seharusnya sudah disesuaikan dengan peraturan yang terbaru. Permasalahan ini membuat mahasiswa menjadi kebingungan sehingga kurang tertarik mengikuti kegiatan pembelajaran. Mahasiswa hanya akan membaca atau mempelajari buku jika ada tugas dari dosen dan menjelang Ujian saja. Salah satu yang mempengaruhi mahasiswa termotivasi untuk membaca buku dikarenakan design yang digunakan bagus sehingga menarik untuk membacanya. Menurut Hartley (1985) ada beberapa karakteristik dalam desain buku pembelajaran yaitu: layaout, tipografi, ukuran huruf, gambar, dan tingkat kesulian. Keunggulan bahan ajar mata kuliah pembelajaran IPS dibandingkan dengan bahan ajar perencanaan yang sudah ada yaitu memberikan materi yang disesuaikan dengan keadaan pendidikan sekarang. Materi mencakup membuat silabus dan RPP dengan memperhatikan semua komponen dalam pembuatannya. Selain itu, materi disusun dengan menarik sehingga mahasiswa memiliki motivasi untuk membacanya.

Selain dari segi desain teks pembelajaran, isi dari sebuah buku juga turut mempengaruhi tingkat ketertarikan seseorang untuk membaca atau mempelajarinya. Dari kedalaman isi materi, buku yang dikembangkan perlu disesuaikan dengan paradigman atau pandangan yang sekarang ini berkembang, sehingga mahasiswa akan lebih mengerti dan tidak kesulitan memahaminya. Saat ini pendekatan pembelajaran bergeser dari behavioristik menjadi konstruktivistik dan hal itu turut mempengaruhi bagaimana seorang dosen dalam mengelola kelas. Dalam pendekatan konstruktivisme, belajar dipahami sebagai kegiatan manusia membangun atau menciptakan pengetahuan dengan cara memberi makna pada pengetahuan sesuai dengan pengalamannya. Dalam pandangan konstruktivisme pengetahuan bukanlah konsep, fakta, yang perlu untuk dingat tetapi lebih pada mengerti makna dan pesan yang disampaikan pada buku tersebut (Rofi'udin, 2017).

Bahan ajar yang dikembangkan menggunakan model Four D (4D). Berbeda dengan model desain pembelajaran yang berpijak pada pendekatan behavioristik, model 4D memiliki karakteristik antara lain: (1) 
Proses pengembangan yang bersifat non linier, tidak beraturan; (2) Perencanaan yang bersifat kolaboratif, berkembang, organif, dan reflektif, (3) Tidak menganggap tujuan sebagai panduan dalam mengembangkan dan mendesain; (4) Tidak diperlukan desain instruksional.

Hasil penelitian yang dilakukan oleh Mahmuludin (2007) menyatakan bahwa produk yang dikembangkan dengan menggunakan model 4D dapat menciptakan mahasiswa aktif untuk berfikir dalam belajar dan memberi suasana yang menyenangkan. Berdasarkan beberapa pertimbangan tesebut, diharapkan dengan adanya bahan ajar mata kuliah Pembelajaran IPS yang menggunakan model 4D dapat meningkatkan motivasi mahasiswa, kritis dan interaktif dalam menjawab masalah yang dikemukakan oleh pendidik. Di samping itu, bahan ajar ini diharapkan dapat membantu dosen dalam menyampaikan materi yang sesuai dengan perkembangan paradigma sekarang.

Tujuan dari penelitian ini adalah (1) untuk mendeskripsikan pengembangan bahan ajar mata kuliah Pembelajaran IPS SD dengan model 4D untuk mahasiswa PGSD Universitas Bhinneka PGRI, dan (2) untuk meningkatkan motivasi belajar mahasiswa PGSD.

\section{Metode}

Metode yang digunakan dalam penelitian ini adalah research and development. Model pengembangan yang dipergunakan adalah Four D (4D). Model pengembangan 4D terdiri atas 4 tahap utama yaitu: (Pendefinisian),

(Perancangan), (Pengembangan) dan (Penyebaran). Metode dan model ini dipilih karena bertujuan untuk menghasilkan produk berupa bahan ajar buku teks. Produk yang dikembangkan kemudian diuji kelayakannya dengan validitas dan uji coba produk untuk mengetahui sejauh mana peningkatan pemahaman, motivasi belajar mahasiswa setelah pembelajaran menggunakan buku teks mata kuliah Pembelajaran IPS SD. Prosedur penelitian yang dilaksanakan dalam penelitian ini meliputi tiga tahap yaitu pra lapangan, pekerjaan lapangan, dan analisis data digambarkan dengan alur sebagai berikut.

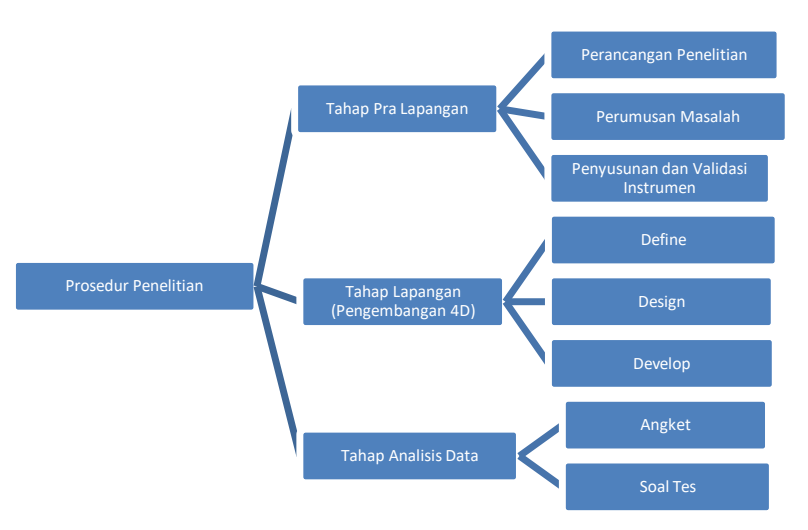

Desain penelitian yang digunakan adalah pengembangan model 4-D dengan tahapan sebagai berikut:

\section{Tahap pendefinisian (define)}

Tahap ini berguna untuk menentukan dan mendefinisikan kebutuhan di dalam proses pembelajaran serta mengumpulkan berbagai informasi yang berkaitan dengan produk yang akan dikembangkan. Kegiatan yang dilakukan 
dalam penentuan ini mencakup tiga hal, yakni (a) menciptakan dan mendukung tim partisipasi, (b) Penyelesaian masalah, dan (c) Pengembangan pemahaman kontens.

\section{Tahap Perancangan (design)}

Bertujuan untuk merancang suatu bahan ajar yang dapat digunakan dalam mata kuliah pembelajaran IPS. Tahap perancangan ini meliputi:

a. Penyusunan Tes

Penyusunan tes instrumen berdasarkan penyusunan capaian pembelajaran yang menjadi tolak ukur kemampuan mahasiswa.

b. Pemilihan Media

Untuk mengidentifikasi media pembelajaran yang cocok/sesuai dengan karakteristik materi dan sesuai dengan kebutuhan mahasiswa.

c. Pemilihan Format

Pemilihan format dilakukan agar format yang dipilih sesuai dengan materi bahan ajar. Pemilihan bentuk penyajian disesuaikan dengan media pembelajaran yang digunakan. Selain itu, digunakan untuk mendesain isi pembelajaran, pemilihan sumber belajar, dan pendekatan, mengorganisasikan dan merancang isi bahan ajar, membuat desain bahan ajar.

\section{d. Desain Awal (initial design)}

Desain awal (initial design) yaitu rancangan bahan ajar buku teks yang telah dibuat oleh peneliti kemudian diberi masukan oleh ahli materi dan ahli desain.
Masukan dari para reviewr akan digunakan untuk memperbaiki bahan ajar buku teks sebelum dilakukan produksi. Kemudian melakukan revisi setelah mendapatkan saran perbaikan pengembangan bahan ajar dan dilanjutkan tahap validasi. Rancangan ini berupa Draft I dari bahan ajar buku teks.

\section{Tahap Pengembangan (develop)}

Tahap pengembangan ini bertujuan untuk menghasilkan bahan ajar yang sudah direvisi berdasarkan masukan ahli dan uji coba kepada mahasiswa. Terdapat dua langkah dalam tahapan ini yaitu sebagai berikut:

a. Validasi Ahli

Validasi ahli ini berfungsi untuk memvalidasi konten materi buku teks pembelajaran. Dalam pengembangan buku teks sebelum dilakukan uji coba dan hasil validasi akan digunakan untuk melakukan revisi produk awal. Buku teks yang telah disusun kemudian akan dinilai oleh ahli materi dan dosen ahli desain, sehingga dapat diketahui apakah buku teks tersebut layak diterapkan atau tidak. Hasil dari validasi ini digunakan sebagai bahan perbaikan untuk kesempurnaan buku teks yang dikembangkan. Setelah draf pertama divalidasi dan direvisi, maka akan dihasilkan draf kedua yang selanjutnya akan diujikan kepada siswa dalam tahap uji coba lapangan terbatas.

\section{b. Uji Coba Produk (development testing)}

Setelah dilakukan validasi ahli kemudian dilakukan uji coba lapangan terbatas 
untuk mengetahui hasil penerapan buku teks dalam pembelajaran di kelas. Desain ujicobaproduk yang dilakukan meliputi beberapa tahap yaitu (1) review ahli media, (2) review ahli materi, (3) uji coba perorangan, (4) uji coba kelompok kecil, dan (5) uji coba lapangan atau kelompok besar. Dimana penjabarannya adalah sebagai berikut:

1. ahli media bertujuan meperoleh penilaian, pendapat, dan saran tentang desin produk bahan ajar yang akan dikembangkan. Ahli media adalah seseorang yang memiliki keahlian di bidang media pembelajaran.

2. Ahli materi yaitu dosen yang memiliki pengetahuan dan menguasai materi-matei dalam mata kuliah Pendidikan IPS SD. Ahli materi dalam hal ini adalah dosen pengampu mata kuliah Pendidikan IPS SD yang akan memberi penilaian, pendapat, dan saran tentang materi-materi yang disajikan dalam produk bahan ajar yang akan dikembangkan.

3. Audience yaitu sasaran pengguna produk yang dikembangkan. Tujuannya yaitu untuk memperoleh penilaian, pendapat, dan saran tentang tingkat efektifitas bahan ajar yang akan dikembangkan. Audience yang dijadikan sasaran dalam proses pengembanganbahan ajar Pendidikan IPS SD adalah mahasiswa PGSD Universitas Bhinneka PGRI.

4. Tahap Diseminasi (diseminate)
Setelah uji coba terbatas dan instrumen telah direvisi, tahap selanjutnya adalah tahap diseminasi. Tujuan dari tahap ini adalah menyebarluaskan buku teks. Pada penelitian ini hanya dilakukan diseminasi terbatas, yaitu dengan menyebarluaskan dan mempromosikan produk akhir buku teks secara terbatas kepada mahasiswa PGSD Universitas Bhinneka PGRI.

Instrumen yang digunakan dalam pengumpulan data pada proses pengembangan bahan ajar ini berupa angket dan tes. Angket digunakan untuk mengumpulkan data terdiri dari angket untuk ahli media, ahli materi, dan angket untuk audience. Tes digunakan untuk mengetahui hasil belajar mahasiswa.

Untuk memberikan makna dan mengambil keputusan tentang kualitas produk pengembangan maka digunakan konversi tingkat pencapaian dengan skala 5 seperti yang digambarkan pada tabel berikut:

Tabel 1 Konversi Tingkat Validasi

\begin{tabular}{|c|c|c|}
\hline $\begin{array}{c}\text { Tingkat } \\
\text { Pencapaian }\end{array}$ & Kualifikasi & Keterangan \\
\hline $90-100 \%$ & Sangat baik & $\begin{array}{c}\text { Tidak perlu } \\
\text { revisi }\end{array}$ \\
\hline $75-89 \%$ & Baik & $\begin{array}{c}\text { Tidak perlu } \\
\text { revisi }\end{array}$ \\
\hline $65-74 \%$ & Cukup & Perlu revisi \\
\hline $55-64 \%$ & Kurangbaik & Perlu revisi \\
\hline $0-54 \%$ & Sangatkurang & Perlu revisi \\
\hline
\end{tabular}

\section{Hasil dan Pembahasan}

Hasil dari penelitian ini berupa (1) sebuah buku ajar mata kuliah Pembelajaran IPS SD, (2) penilaian buku ajar oleh ahli materi dan ahli desain pembelajaran. 
tanggapan mahasiswa terhadap buku yang telah dibuat. Buku ajar dikemas secara menarik dan memberikan variasi warna, gambar, penggunaan bahasa yang mudah dipahami sehingga membuat mahasiswa antusias dalam membaca dan mempelajarinya, sistematis dengan menyajikan materi sesuai dengan kurikulum yang berlaku saat ini. Berikut ini disajikan uraian pelaksanaan dan hasil penelitian dan pengembangan dengan mengikuti tahapan model pengembangan 4D yang telah dimodifikasikan menjadi 3D sehingga terdiri atas tiga tahap yaitu tahap pendefinisian (define), tahap perencanaan (design), dan tahap pengembangan (develop).

\section{Tahap Pendefinisian (Define)}

Pada tahap ini yang dilakukan adalah menganalis masalah, analisis mahasiswa, tugas, konsep, dan perumusan capaian pembelajaran.

a. Analisis Masalah

Program Studi PGSD Universitas Bhinneka PGRI (UBHI) melaksanakan perkuliahan dengan berorientasi kurikulum KKNI. Mata kuliah Pembelajaran IPS SD diberikan pada mahasiswa semester IV dengan bobot 3 sks. Mata kuliah ini membahas tentang penerapan pembelajaran IPS di SD. Mahasiswa mengalami kesulitan dalam mencari referensi terkait buku mata kuliah tersebut. Kalau pun ada, jumlah buku masih sedikit dan belum ada contoh aplikatif yang terkait dengan pembelajaran di SD.

b. Analisis Mahasiswa

Karakteristik mahasiswa PGSD UBHI memang berbeda-beda, namun Prodi mengambil kebijakan untuk tidak memisahkan mahasiswa sesuai dengan karakter dan kemampuan akademisnya. Menurut wawancara peneliti dengan salah seorang dosen yang mengampu mata kuliah Pembelajaran IPS SD, mahasiswa cenderung hanya mengandalkan google dari pada buku sebagai sumber referensinya. Ketika diberi tugas untuk membuat silabus dan RPP, mahasiswa banyak yang tidak mengerjakan sendiri, namun mereka mendownload dari situs google. Sehingga, hasil pengerjaannya kurang sesuai dengan Peraturan yang ditetapkan oleh Permenristekdikti.

c. Analisis Materi

Pada tahap ini, peneliti mengidentifikasi secara sistematis konsep-konsep yang akan diajarkan yaitu sebagai berikut : (1) Sejarah perkembangan IPS secara umm dan di Indonesia, (2) Perilaku social, perubahan social, dan konflik social, (3) Konsep ITM dalam IPS, (4) Pendidikan global, (5) Keterampilan mengajar IPS, (6) Metode Pembelajaran IPS, (7) Media dan sumber belajar IPS, (8) Model Pembelajaran IPS.

d. Analisis Tugas 
Pada tahap ini, peneliti mengidentifikasikan tugas yang diperlukan dalam kegiatan perkuliahan. Tugas yang diberikan ada yang secara individu maupun kelompok. Tugas ini isusun berdasarkan Rencana Pelaksanaan Semester (RPS) yang telah dibuat.

e. Perumusan Capaian Pembelajaran

(a) Mahasiswa mampu menguasai konsep dasar lima bidang studi ke-SD-an serta mampu mengimplementasikannya dalam pembelajaran melalui teknologi informasi dan komunikasi secara efektif, empatik dan santun pada peserta didik, (b) menguasai metode dan teknik pengembangan bahan ajar serta mampu mewujudkan secara kreatif., (c) menerapkan metode dan teknik pengembangan media pembelajaran serta mampu mewujudkan secara efektif dan efisien

\section{Tahap Perancangan (Design)}

Setelah melakukan tahap pendefinisian (define) maka produk telah dapat disusun. Berdasarkan analisis awal-akhir, analisis mahasiswa, materi, tugas, dan capaian pembelajaran, tersusunlah produk awal berupa buku mata kuliah Pembelajaran IPS SD. Draft awal produk yang dihasilkan digambarkan sebagai berikut.

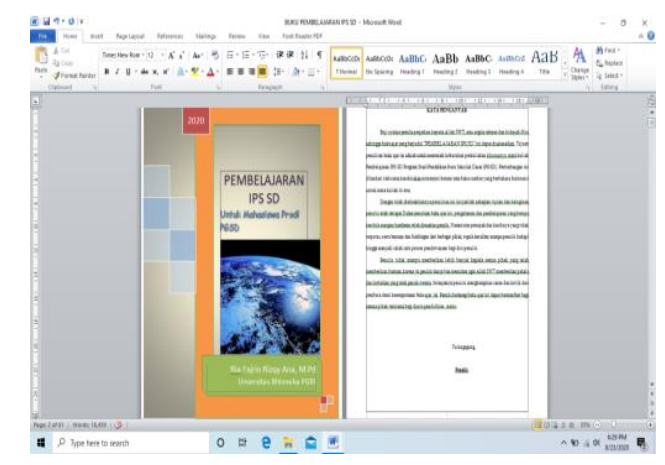

Gambar 1. cover buku teks

Format dalam penyusunan buku ajar ini disesuaikan dengan karakteristik mahasiswa PGSD dan disesuikan dengan dengan pendekatan kontekstual. Buku ajar dibuat semenarik dan seefektif mungkin untuk menarik dan meningkatkan motivasi belajar mahasiswa. Pada tahap ini peneliti juga membuat RPS mata kuliah Pembelajaran IPS SD yang diberikan pada mahasiswa.

\section{Tahap Pengembangan (Develop)}

Pada tahap pengembangan terdapat dua tahap yang dilakukan yaitu validasi oleh tim ahli dan uji coba.

\section{a. Validasi Oleh Tim Ahli}

Draf buku yang dihasilkan dari tahap sebelumnya (tahap pendefinisian dan tahap perancangan) divalidasi oleh para ahli untuk mengetahui validitas buku yang dikembangkan dan mendapatkan masukan dan koreksi yang berguna sebagai dasar untuk melakukan revisi dan penyempurnaan buku. Buku yang telah dinyatakan valid oleh validator kemudian dikembangkan. Berikut adalah hasil penilaian dari segi materi oleh ahli materi Ibu Nourma Oktaviarini, M.Pd.

Tabel 2. Hasil Angket Validasi Ahli Materi

\begin{tabular}{|c|c|c|c|c|c|c|}
\hline \multirow{2}{*}{ No. } & $\begin{array}{c}\text { Isi Pernyataan } \\
\text { Angket }\end{array}$ & \multicolumn{3}{|c|}{ Skor } & \multirow{2}{*}{$\%$} & $\begin{array}{c}\text { Kualivi } \\
\text { kasi }\end{array}$ \\
\cline { 3 - 5 } 1. & $\begin{array}{l}\text { Kejelasan materi } \\
\text { perkuliahan }\end{array}$ & 3 & 3 & 4 & 75 & $\begin{array}{c}\text { Cuku } \\
\text { p }\end{array}$ \\
\hline
\end{tabular}




\begin{tabular}{|c|c|c|c|c|c|c|}
\hline & & & & & & Valid \\
\hline 2. & $\begin{array}{l}\text { Kesesuaian isi } \\
\text { media dengan } \\
\text { materi }\end{array}$ & 4 & 4 & 4 & 100 & Valid \\
\hline 3. & $\begin{array}{l}\text { Kesesuaian } \\
\text { materi dengan } \\
\text { karakteristik } \\
\text { pengguna }\end{array}$ & 4 & 4 & 4 & 100 & Valid \\
\hline 4. & \begin{tabular}{|l} 
Kesesuaian \\
media interaktif \\
dalam menambah \\
motivasi \\
mahasiswa
\end{tabular} & 4 & 4 & 4 & 100 & Valid \\
\hline 5. & \begin{tabular}{|l|} 
Kesesuaian \\
media interaktif \\
dalam \\
meningkatkan \\
efektifitas belajar
\end{tabular} & 4 & 4 & 4 & 100 & Valid \\
\hline 6. & $\begin{array}{l}\text { Kesesuaian isi } \\
\text { materi dengan } \\
\text { tujuan } \\
\text { pembelajaran }\end{array}$ & 4 & 4 & 4 & 100 & Valid \\
\hline 7. & $\begin{array}{l}\text { Kesesuaian buku } \\
\text { dalam menarik } \\
\text { minat belajar } \\
\text { pengguna }\end{array}$ & 3 & 3 & 4 & 75 & $\begin{array}{l}\text { Cuku } \\
\text { Valid }\end{array}$ \\
\hline 8. & $\begin{array}{l}\text { Kesesuaian buku } \\
\text { dalam } \\
\text { mempermudah } \\
\text { penguasaan } \\
\text { materi }\end{array}$ & 4 & 4 & 4 & 100 & Valid \\
\hline 9. & $\begin{array}{l}\text { Konsep buku } \\
\text { sesuai dengan } \\
\text { tujuan } \\
\text { pembelajaran }\end{array}$ & 4 & 4 & 4 & 100 & Valid \\
\hline 10. & $\begin{array}{l}\text { Kesesuaian } \\
\text { waktu tayangan }\end{array}$ & 4 & 4 & 4 & 100 & Valid \\
\hline & & 38 & 38 & 40 & & \\
\hline
\end{tabular}

Berdasarkan pengolahan data ahli materi di atas, secara keseluruhan dapat diperoleh hasil $95 \%$ buku ajar mata kuliah Pembelajaran IPS SD yang dikembangkan termasuk dalam kriteria valid/layak dan dapat digunakan dalam proses pembelajaran.

Selanjutnya penilaian dari validator ahli desain terhadap desain Buku Mata Kuliah Pembelajaran IPS SD oleh Bapak Rahmad Setyo Jadmiko, M.Pd. dan Bapak Reyhan Florean, M.Pd. diperoleh data sebagai berikut.

Tabel 2 Hasil Angket dari Ahli Media

\begin{tabular}{|c|c|c|c|c|c|c|c|}
\hline \multirow{2}{*}{ No } & \multirow{2}{*}{\begin{tabular}{|c|}
$\begin{array}{c}\text { Isi Pernyataan } \\
\text { Angket }\end{array}$ \\
\end{tabular}} & \multicolumn{4}{|c|}{ Skor } & \multirow{2}{*}{$\%$} & \multirow{2}{*}{$\begin{array}{c}\text { Kualif } \\
\text { ikasi }\end{array}$} \\
\hline & & $\mathbf{x 1}$ & $\mathrm{x} 2$ & $\Sigma \mathbf{x}$ & $\Sigma \mathbf{x}_{\mathbf{i}}$ & & \\
\hline 1 & $\begin{array}{l}\text { Kesesuaian } \\
\text { ukuran dengan } \\
\text { materi isi buku }\end{array}$ & 4 & 4 & 8 & 8 & 100 & $\begin{array}{c}\text { vali } \\
\mathrm{d}\end{array}$ \\
\hline 2 & $\begin{array}{l}\text { Penampilan } \\
\text { unsur tata letak } \\
\text { pada sampul } \\
\text { muka, } \\
\text { belakang, dan } \\
\text { punggung } \\
\text { secara } \\
\text { harmonis } \\
\text { memiliki irama } \\
\text { dan kesatuan } \\
\text { (unity) secara } \\
\text { konsisten }\end{array}$ & 4 & 4 & 8 & 8 & 100 & $\begin{array}{c}\text { vali } \\
\mathrm{d}\end{array}$ \\
\hline 3 & $\begin{array}{l}\text { Menampilkan } \\
\text { pusat pandang } \\
\text { (center point) } \\
\text { yang baik }\end{array}$ & 4 & 3 & 7 & 8 & 87,2 & $\begin{array}{c}\text { vali } \\
\mathrm{d}\end{array}$ \\
\hline 4 & $\begin{array}{l}\text { Komposisi dan } \\
\text { ukuran unsur } \\
\text { tata letak } \\
\text { (judul, } \\
\text { pengarang, } \\
\text { ilustrasi, logo, } \\
\text { dll) } \\
\text { proporsional, } \\
\text { seimbang dan } \\
\text { seirama dengan } \\
\text { tata letak isi } \\
\text { (sesuai pola) }\end{array}$ & 4 & 4 & 8 & 8 & 100 & $\begin{array}{c}\text { vali } \\
\text { d }\end{array}$ \\
\hline 5 & $\begin{array}{l}\text { Warna unsur } \\
\text { tata letak } \\
\text { harmonis dan } \\
\text { memperjelas } \\
\text { fungsi }\end{array}$ & 4 & 3 & 7 & 8 & 87,5 & $\begin{array}{c}\text { vali } \\
\text { d }\end{array}$ \\
\hline 6 & $\begin{array}{l}\text { Ukuran huruf } \\
\text { judul buku } \\
\text { lebih dominan } \\
\text { dan } \\
\text { proporsional } \\
\text { dibandingkan } \\
\text { ukuran buku, } \\
\text { nama } \\
\text { pengarang }\end{array}$ & 4 & 4 & 7 & 8 & 87,5 & $\begin{array}{c}\text { vali } \\
\text { d }\end{array}$ \\
\hline 7 & $\begin{array}{l}\text { Warna judul } \\
\text { buku kontras } \\
\text { dengan warna } \\
\text { latar belakang }\end{array}$ & 4 & 4 & 8 & 8 & 100 & $\begin{array}{c}\text { vali } \\
\mathrm{d}\end{array}$ \\
\hline 8 & Tidak & 4 & 4 & 8 & 8 & 100 & vali \\
\hline
\end{tabular}




\begin{tabular}{|c|l|c|c|c|c|c|c|}
\hline & $\begin{array}{l}\text { menggunakan } \\
\text { terlalu banyak } \\
\text { kombinasi jenis } \\
\text { huruf }\end{array}$ & & & & & d \\
\hline 9 & $\begin{array}{l}\text { Bentuk, warna, } \\
\text { ukuran, } \\
\text { proporsi objek } \\
\text { sesuai dengan } \\
\text { realita }\end{array}$ & 4 & 4 & 8 & 8 & 100 & $\begin{array}{c}\text { vali } \\
\text { d }\end{array}$ \\
\hline 10 & $\begin{array}{l}\text { Pemisahan } \\
\text { antar paragraf } \\
\text { jelas }\end{array}$ & 4 & 4 & 8 & 8 & 100 & $\begin{array}{c}\text { vali } \\
\mathrm{d}\end{array}$ \\
\hline 11. & $\begin{array}{l}\text { Spasi antar } \\
\text { huruf normal }\end{array}$ & 3 & 3 & 6 & 8 & 75 & $\begin{array}{c}\text { up } \\
\text { vali } \\
\text { d }\end{array}$ \\
\hline 12. & $\begin{array}{l}\text { Mampu } \\
\text { mengungkap } \\
\text { makna/arti dari } \\
\text { objek }\end{array}$ & 3 & 3 & 6 & 8 & 75 & $\begin{array}{c}\text { up } \\
\text { vali } \\
\text { d }\end{array}$ \\
\hline 13 & $\begin{array}{l}\text { Bentuk akurat } \\
\text { dan } \\
\text { proporsional } \\
\text { sesuai dengan } \\
\text { kenyataan }\end{array}$ & 4 & 4 & 8 & 8 & 100 & $\begin{array}{c}\text { vali } \\
\text { d }\end{array}$ \\
\hline 14 & $\begin{array}{l}\text { Penyajian } \\
\text { keseluruhan } \\
\text { ilustrasi serasi }\end{array}$ & 4 & 4 & 8 & 8 & 100 & $\begin{array}{c}\text { vali } \\
\mathrm{d}\end{array}$ \\
\hline 15 & $\begin{array}{l}\text { Kreatif dan } \\
\text { dinamis }\end{array}$ & 4 & 3 & 7 & 8 & 87,5 & $\begin{array}{c}\text { vali } \\
\mathrm{d}\end{array}$ \\
\hline & & $\mathbf{5 8}$ & $\mathbf{1 1 2}$ & $\mathbf{1 2 0}$ & $\mathbf{9 3 , 3}$ & $\begin{array}{c}\text { vali } \\
\mathbf{d}\end{array}$ \\
\hline
\end{tabular}

Berdasarkan pengolahan data ahli media di atas, secara keseluruhan dapat diperoleh hasil 93,3\% dalam kriteria valid/layak dan dapat digunakan dalam kegiatan pembelajaran.

\section{b. Revisi Desain}

Sebelum buku diimplementasikan, peneliti melakukan perbaikan terlebih dahulu terhadap buku yang sudah melalui tahap validasi. Revisi dilakukan peneliti berdasarkan pendapat dan penilaian tim ahli terhadap materi dan desain buku yang telah dibuat. Pada tahap ini dilakukan perbaikan buku berdasarkan saran dan komentar dari tim ahli atau validator tersebut.

\section{Revisi ahli media/design}

Revisi ahli media ini diambil dari 2 orang ahli media. Berdasarkan angket yang diberikan kepada 2 orang ahli media tersebut dapat diperoleh tanggapan sebagai berikut, (1) Spasi antar huruf diperbaiki sesuikan dengan bakunya, (2) Perhatikan penggunaan huruf kapitalnya, (3) Font judul kurangi ukurannya,

(4) Gunakan warna yang menarik

\section{Revisi ahli materi}

Revisi ahli materi ini diambil dari 1 orang ahli materi. Berdasarkan angket yang diberikan kepada 1 orang ahli materi tersebut dapat diperoleh tanggapan sebagai berikut, (1) Pembuatan silabus sesuaikan dengan SK dan KD RPP, (2) Tambahkan komponen dari silabus dan RPP.

\section{Uji Coba}

Setelah dilakukan revisi hasil masukan dari ahli materi dan ahli design, buku ajar diujicoba secara perseorangan. Berdasarkan pengolahan data dari uji coba perorangan, secara keseluruhan dapat diperoleh hasil 87,5\% termasuk dalam kriteria valid/layak dan dapat digunakan dalam proses pembelajaran. Kemudian dilakukan uji coba kelompok kecil pada 12 mahasiswa semester IV Prodi PGSD UBHI. Berdasarkan hasil audiens kelompok kecil, diperoleh hasil 84,17 $\%$, sehingga buku ajar dinyatakan valid/layak digunakan. Pada uji coba lapangan, dilakukan 
kegiatan pembelajaran menggunakan buku teks mata kuliah Pembelajaran IPS SD yang telah dikembangkan melalui tahapan validasi ahli, uji coba, dan revisi. Kegiatan ini dilakukan terhadap mahasiswa yang berjumlah 37 mahasiswa. Pada tahap uji coba lapangan mahasiswa diberikan buku teks untuk mengetahui keefektifan dari buku ajar yang sudah dibuat. Hasil dari uji coba lapangan diperoleh hasil 90,88\%, sehingga produk buku layak digunakan untuk kegiatan pembelajaran.

Prosentase ketuntasan belajar mahasiswa mencapai $89,1 \%$. Mahasiswa dikatakan tuntas belajarnya apabila memperoleh nilai rata-rata $\geq 70$ dan satu kelas dikatakan tuntas belajar apabila dikelas tersebut terdapat $85 \%$ mahasiswa telah tuntas belajar. Hal ini menunjukkan bahwa buku teks ini memberikan efek positif terhadap hasil belajar mahasiswa. Nilai dari hasil tes ini tidak dijadikan ukuran untuk mengukur tingkat prestasi mahasiswa secara signifikan, tetapi hanya sebagai alat pembanding efektifitas saat sebelum dan sesudah menerima bahan ajar berupa buku teks mata kuliah Pembelajaran IPS SD.

\section{Kesimpulan}

Pengembangan bahan ajar mata kuliah Pembelajaran IPS SD meliputi define, design, dan develop. Pada tahap design meliputi penyusunan buku teks, pembuatan RPS, dan penyusunan angket. Develop telah dihasilkan buku yang telah dicetak. Setelah itu dilakukan tahap evaluasi dengan tujuan untuk mendapatkan penilaian, komentar, dan saran dalam penyempurnaan buku tersebut.

Efektifitas pengembangan buku teks dilihat dari pencapaian ketuntasan belajar mahasiswa. Berdasarkan hasil penelitian pada uji coba lapangan, dari 37 orang mahasiswa yang mengikuti tes terdapat 33 orang mahasiswa $(89,1 \%)$ yang tuntas atau mencapai KKM.

\section{Daftar Pustaka}

Agus, S. 2003. Ilmu Alam,(online) (http://id.wikipedia.org/wiki/Ilmu alam diakses 12 Januari 2020

Budiman,2016.ModelPembelajaranModul. http://primasoft.wordpress.com/2008/03/3 1/modular-intruction-pembelajaranmenggunakan-modul/ (diakses 13 Januari 2020)

Prastowo, Andi. 2017. Pengembangan Pembelajaran.http://andiprastowo.wordpr ess.com/2017/01/14/pengembanganpembelajaran/(diakses 14 Januari 2020).

Ramandanu, Febriana. 2019. Pengembangan Buku . Jurnal Mimbar Ilmu Universitas Pendidikan Ganesha. 24(1):10-19. https://ejournal.undiksha.ac.id/index.ph $\mathrm{p} / \mathrm{MI} /$ article/view/17405

Sadiman, dkk. 2008. Media Pendidikan: Pengertian, Pengembangan, dan Pemanfaatan. Jakarta: Depdikbud Pustekom. PT. Raja Grafindo Persada

Sa'ud, S. 2008. Inovasi Pendidikan. Bandung. Alfabeta

Sell.B \& Richiy.R AECT (Association for Education Communication and Technology).1994.Definisi Teknologi Pendidikan.Terjemahan Edisi Indonesia.Jakarta:CV Rajawali

Setyosari, Trianto.2007. Model Pengembangan Pembelajaran Menurut Thiagarajan,(online),(http://badarudinalba 
nna.wordpress.com/2017/01/12/model-

pengembangan-perangkat-desain-

pembelajaran/diakses 12 Januari 2018)

Sudjana, N. 2003. Pengantar Statistik Pendidikan. Jakarta: Raja Grafindo Persada

Sudjana, N. 2003. Teknologi Pengajaran.Bandung: Sinar Baru Algensindo.

Ramandanu, Febriana. 2019. Pengembangan Model Four D Untuk Meningkatkan Motivasibelajar.. Jurnal Mimbar Ilmu Universitas Pendidikan Ganesha. 24(1):10-19. https://ejournal.undiksha.ac.id/index.ph $\mathrm{p} / \mathrm{MI} /$ article/view/17405

Rofi'uddin, Moh Adib. 2017. Pengaruh Bahan Ajar Terhadap Motivasi Belajar. Jurnal Ilmu Perpustakaan. 6(1): 281-290. https://ejournal3.undip.ac.id/index.php/ jip/article/view/23086

Susanto, A. (2016). Teori Belajar \& Pembelajaran di Sekolah Dasar. Jakarta: Prenadamedia Group.Peraturan Menteri Pendidikan dan Kebudayaan RI Nomor 23 Tahun 2015 tentang Penumbuhan Budi Pekerti.

Tarmidzi, 2020. Pengaruh Kegiatan Literasi Terhadap Minat Baca Siswa di Sekolah Dasar.3(1), 40-51.

Wirna. 2019. Pengembangan Bahan Ajar Berbasis Kearifan Lokal.http://repositori.uinalauddin.ac.id/1 5222/1/WIRNA.pdf

Yatmono, Yulianti, D., \& Ahlis, I. 2013. Bahan Ajar Fisika Online untuk Mengembangkan Kemandirian dan Minat Belajar Siswa pada Pokok Bahasan Kalor. Unnes Physics Educaion Journal (UPEJ), 2 (2), 1-7. 